\title{
Connectivity of the Taiwan, Cheju, and Korea straits
}

\author{
W.J. Teague ${ }^{\mathrm{a}, *}$, G.A. Jacobs ${ }^{\mathrm{a}}$, D.S. Ko ${ }^{\mathrm{a}}$, T.Y. Tang ${ }^{\mathrm{b}}$, K.-I. Chang ${ }^{\mathrm{c}}$, M.-S. Suk \\ ${ }^{a}$ Naval Research Laboratory, Stennis Space Center, MS 39529-5004, USA \\ ${ }^{\mathrm{b}}$ Institute of Oceanography, National Taiwan University, Taipei, Taiwan \\ ${ }^{\mathrm{c}}$ Korea Ocean Research and Development Institute, Seoul, South Korea
}

Received 23 July 2001; received in revised form 30 May 2002; accepted 14 August 2002

\begin{abstract}
Insight into the circulation of the East China Sea and origin of the Tsushima Current are investigated through direct, concurrent measurements of velocities through the Taiwan, Cheju, and Korea Straits. Current data are obtained from six bottom-mounted acoustic Doppler current profilers (ADCPs) arrayed along a section spanning the Korea Strait, a single bottom-moored ADCP in the Cheju Strait, and four bottom-moored ADCPs along a section spanning the Taiwan Strait. Mass transports are computed for the October-December, 1999 time period. In addition, temperature and salt transports are examined in conjunction with climatological values of temperature and salinity. Average volume transport is 0.14 Sverdrups (Sv) through the Taiwan Strait, 0.59 Sv for the Cheju Strait, and $3.17 \mathrm{~Sv}$ for the Korea Strait. Salt and temperature transport through the Korea Strait and into the Japan/East Sea are $110.48 \times 10^{6} \mathrm{~kg} / \mathrm{s}$ and $0.24 \times 10^{15}$ watts (W), respectively. Heat loss in the East China Sea is approximately $200 \mathrm{~W} / \mathrm{m}^{2}$. Winds affect the transports in each of the straits. Most noticeable wind effects are observed in the Taiwan Strait where strong north wind events force flow into the South China Sea. The main source for the Tsushima Current and its flow into the Japan/East Sea is clearly the Kuroshio for fall, 1999.
\end{abstract}

Published by Elsevier Science Ltd.

Keywords: Acoustic current meters; BT; Coastal waters; NT; Current data; RT; Mass transport; RT; Temperature transport; RT; Physical oceanography; BT

\section{Introduction}

The main currents flowing into the East China Sea and ultimately the Yellow and the Japan/East Sea are the Kuroshio (KUR), entering through the passage between Taiwan and Yonaguni-jima (an island at the southwestern tip of the Ryuku Islands) and flowing along the shelf break, and the Taiwan Warm Current (TWC) entering

\footnotetext{
*Corresponding author. Tel.: + 1-228-688-4734; fax: + 1228-688-5997.

E-mail address: teague@nrlssc.navy.mil (W.J. Teague).
}

through the Taiwan Strait from the South China Sea. The bulk of the KUR exits the East China Sea through the Tokara Strait, located just southwest of Kyushu. The transport of the KUR into the East China sea is estimated to average about $23 \mathrm{~Sv}$, both annually and for the fall (Hsueh et al., 1992; Ichikawa and Chaen, 2000; Ichikawa and Beardsley, 1993; Johns et al., 2001). Zhang et al. (2001) found that the KUR transport entering the East China Sea is strongly related to meandering of the Kuroshio caused by westward propagating anticyclonic eddies from the interior ocean, and that during low transport events, the 
KUR meanders offshore and partly bypasses the East China Sea to flow northward along the eastern side of the Ryukyu Islands.

Historically, the TWC has been interpreted as a branch of the KUR (Wyrtki, 1961; Chuang, 1986; Lie and Cho, 1994). However, source waters for the TWC are formed in the northern South China Sea and origins of the circulation patterns there are relatively unknown (Wang and Chern, 1996). Very few direct current measurements of the region have been made and the velocity variations of the TWC are largely unknown. Upon entering the East China Sea, the TWC is hypothesized to either remain separated from the KUR (Beardsley et al., 1985; Fang et al., 1991) and maintain its identity, or to commingle with and rejoin the KUR at the shelf edge (Chern and Wang, 1992; Schultz, 1994). Intrusion of the KUR onto the shelf can block Taiwan Strait inflow into the East China Sea (Tang et al., 2000).

The origin of the Tsushima Current (TSC) has been investigated through conductivity, temperature, and depth (CTD) surveys, surface drifter experiments, satellite observations of the sea surface, velocity measurements through shipmounted acoustic Doppler profilers (ADCPs), and more limited direct velocity measurements through moorings. There are two theories on the origin of the TSC. In the earliest theory, a simple flow pattern for the East China Sea proposed by Uda (1934) consists of the TSC originating from the KUR and flowing into the Japan/East Sea (hereafter, JES) through the Korea Strait, and with the Yellow Sea Warm Current (YSWC) separating from the TSC southeast of Cheju. Based on temperature and salinity measurements, Nitani (1972) suggested that the TSC separates from the KUR at about $30.5^{\circ} \mathrm{N}, 129^{\circ} \mathrm{E}$ and then flows northward on the left flank of the deep trough west of Kyushu (Fig. 1a). The YSWC is also shown to originate off the TSC southeast of Cheju. In a more recent theory proposed by Beardsley et al. (1985) and Fang et al. (1991), the TSC is suggested to be a continuation of the TWC on entering the East China Sea through the Taiwan Strait (Fig. 1b). In addition, the YSWC also forms off the TSC southwest of Cheju.
The climatological mean northward flow in the Yellow Sea trough has historically been referred to as the YSWC since it was thought to originate as a branch of the TSC which transports warm KUR waters. Recent studies have found this to be false. During fall transition and winter monsoon periods, strong northerly wind bursts drive a north-tosouth pressure-gradient increase extending from the Yellow Sea trough over to the Korean coast and force a northward flow in the trough (Hsueh, 1988; Teague and Jacobs, 2000). During summer, the YSWC is a result of weak southerly winds (Teague and Jacobs, 2000).

The Cheju Warm Current (CWC), defined as the mean eastward flow in the Cheju Strait, is a major conduit for water exchange between the Yellow and East China Seas and the JES. The CWC is partly formed by TSC waters that are believed to flow clockwise around Cheju (Kim et al., 1991a; Chang et al., 2000) instead of branching south of Cheju and forming the YSWC. The CWC transports mostly high temperature and salinity waters originating from the KUR (Chang et al., 2000; Lie et al., 2000) and also transports relatively fresh waters of various origins from the Yellow Sea (Kim et al., 1991b; Cho and Kim, 1994) and from the Yangtze Bank vicinity off China (Beardsley et al., 1985; Park, 1986; Kim et al., 1991a; Kim and Rho, 1994).

The heat and salt balances within the Yellow and East China Seas are determined in large part by inflows of the TWC and KUR. These in turn play a major role in the heat and salt balances in the JES through the TSC inflow. Understanding of the relationships and forcing mechanisms of the flows through various straits is important for understanding the circulation in these Asian seas. Ultimately, the Yellow and East China Seas, and the JES, connected with the North Pacific through the Tokara and Tsugaru Straits, play an important role in determining the temperature and salinity characteristics in the North Pacific circulation. The connectivity of the transports, and temperature and salinity fluxes between Taiwan, Cheju, and the Korea Straits are analyzed for fall of 1999 using concurrently observed transports through each strait and climatological temperature and salinity in this paper. 


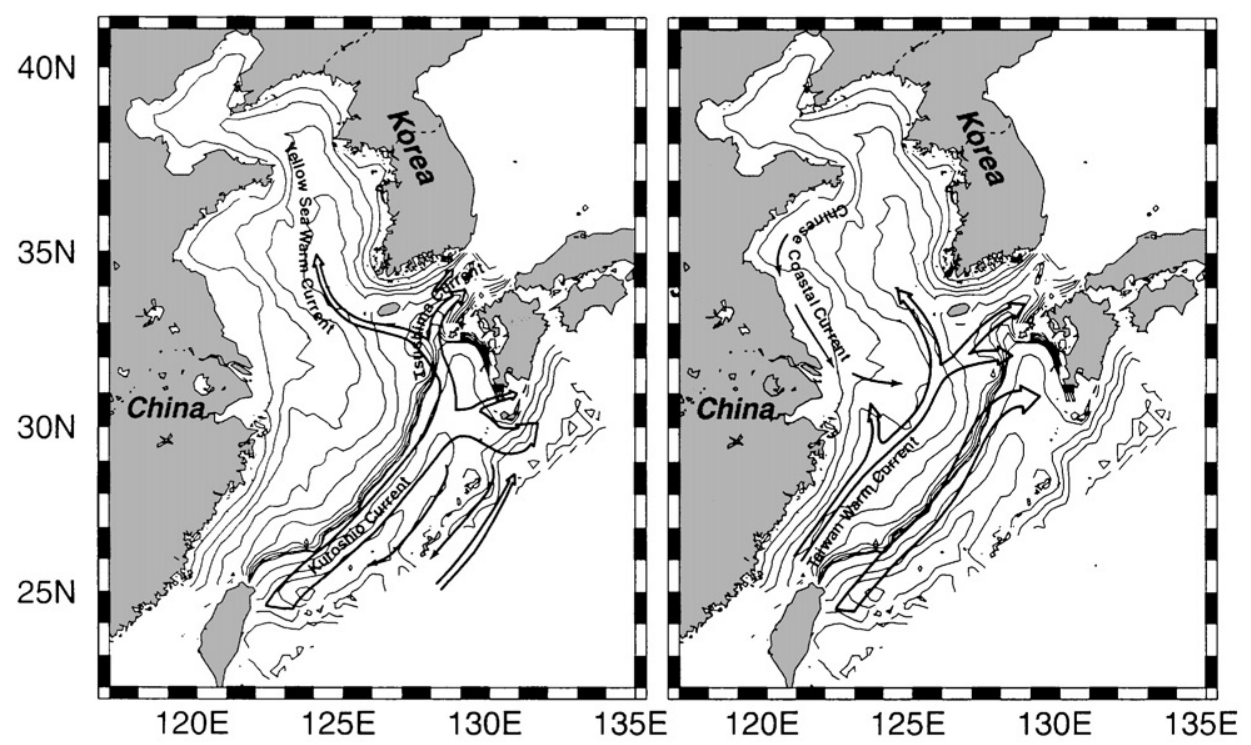

(a)

(b)

Fig. 1. (a) Results adapted from Nitani (1972) suggest that the Kuroshio Current is the main source of inflow for the Tsushima Current. The Yellow Sea Warm current is also hypothesized to form off the Tsushima Current, (b) results adapted from Beardsley et al. (1985) suggest that the Taiwan Warm Current is the main source for the Tsushima Current and a Yellow Sea Warm Current.

\section{Observed transports}

The United States Naval Research Laboratory (NRL) deployed six bottom moored acoustic Doppler current profilers (ADCPs) along a section spanning the Korea Strait, southwest of Tsushima Island, from May 1999 through March 2000 (Perkins et al., 2000; Teague et al., 2002). Each ADCP is housed in a trawl-resistant bottom mount and measures near full water column current profiles. A similar mooring was deployed just north of Cheju in the Cheju Strait by the Korea Ocean Research and Development Institute (KORDI) from March 1999 to December 1999. In addition, the National Taiwan University deployed four bottom moored ADCPs in trawl resistant mounts across the Taiwan Strait between Wuchiu and Taichung from October through December 1999. Hence the data sets in the Korea Strait, Cheju Strait, and Taiwan Strait overlap for three months, during fall 1999. The instruments, protected within the mounts, rest about $0.5 \mathrm{~m}$ above the ocean bottom. The ADCPs are set up to provide current profiles with an accuracy of $1 \mathrm{~cm} / \mathrm{s}$ over nearly the full water column. Vertical resolution was set at either 2 or $4 \mathrm{~m}$. Profiles of $U$ (east-west) and $V$ (north-south) components of velocity are recorded at $30 \mathrm{~min}$ intervals in the Korea Strait and 60 min intervals in the Taiwan Strait. The mooring locations and bathymetry are shown in Fig. 2.

For computation of the volume transports in the Korea Strait and Cheju Strait, tidal currents and currents near the tidal semi-diurnal and diurnal frequencies are removed from the ADCP records by using a low-pass filter with a $40 \mathrm{~h}$ cutoff frequency. Velocities are then rotated $\left(42.5^{\circ}\right)$ so that the velocity components are approximately along strait (normal to the ADCP section spanning the Korea Strait) and cross strait (approximately parallel to the ADCP section). The Korea Strait transports are fully discussed by Jacobs et al. (2001) and by Teague et al. (2002). In brief, an optimal interpolation (OI) scheme is used to interpolate the data spatially and to provide an error estimate. The horizontal length scales in the Korea Strait determined by Jacobs et al. (2001) are between 15 and $30 \mathrm{~km}$. Since the ADCP spacing along the Korea Strait section is about $25 \mathrm{~km}$, measurements along this section are just capable 


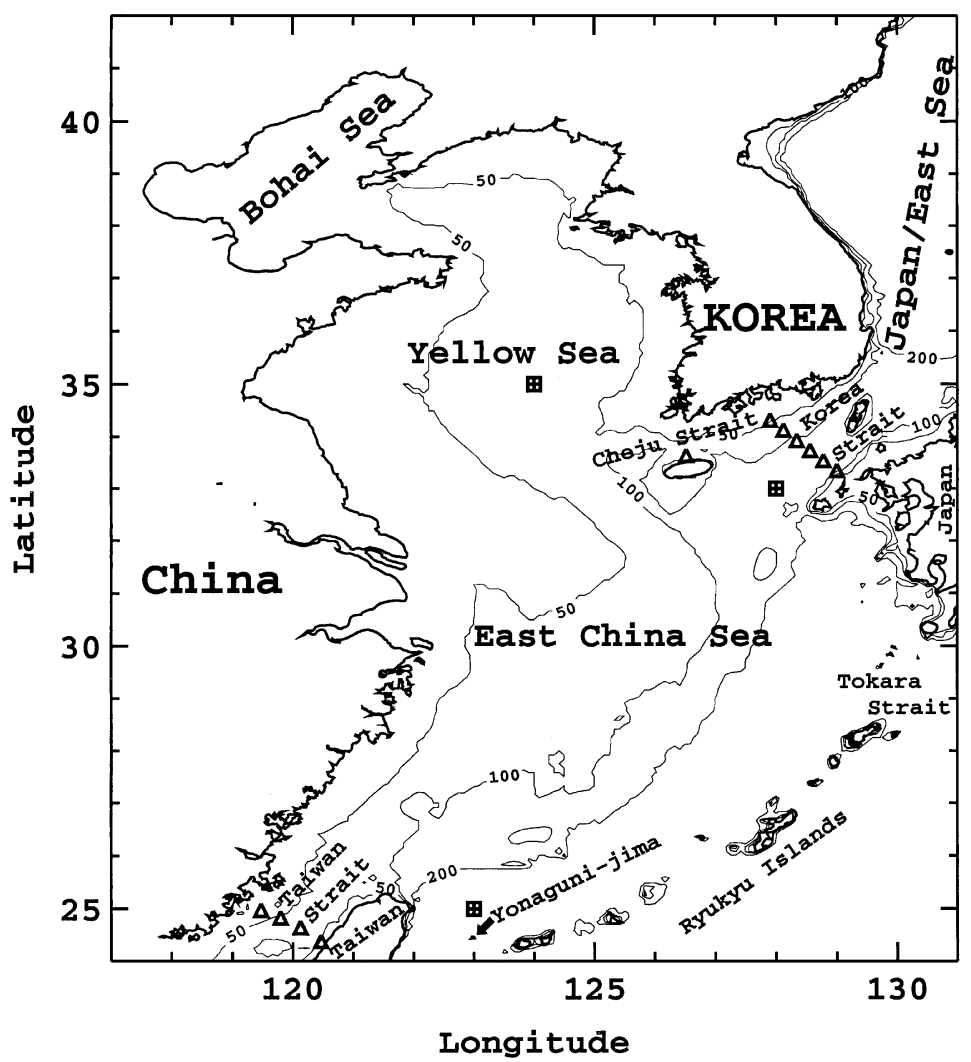

Fig. 2. Mooring locations (triangles) are indicated in the Taiwan, Cheju, and Korea Straits. Wind observation positions (boxes with plus signs) are located near the Taiwan Strait, in the Yellow Sea, and in the Korea Strait. Bathymetry is in meters.

of resolving typical horizontal scales. However, high-resolution snapshots of currents across the strait obtained by a ship-mounted ADCP (Isobe, 1994) indicate currents narrower than the mooring spacing sometimes occur and could be a source for error. Vertical length scales also determined by Jacobs et al. (2001) are roughly $20 \mathrm{~m}$ near the bottom and decrease toward the surface, and thus are well resolved except near the surface. The measurements do not resolve the near-surface layer and thus surface current intensification could be a source of error. Transports through the strait are computed by vertically integrating the interpolated velocity section. The time average alongstrait transport for May 1999-March 2000 is 2.7 Sv and the time average along-strait transport for October-December 1999 is $3.17 \mathrm{~Sv}$. Expected errors in the transport estimate, based on horizontal and vertical length scales observed by the instruments, at any time, are about $0.5 \mathrm{~Sv}$ RMS (Jacobs et al., 2001).

The velocity components from the ADCPs across the Taiwan Strait are similarly low-passed to remove tides and then rotated. Following the technique also used in the Korea Strait and described in Jacobs et al. (2001), an OI scheme is used to interpolate and extrapolate the ADCP observations to calculate transport and to provide an error estimate. Horizontal length scales in the Taiwan Strait are found to range from about 50 to $100 \mathrm{~km}$. The mooring spacing of about $40 \mathrm{~km}$ can resolve the typical horizontal length scales. The vertical length scales in the Taiwan Strait range from about 40 to $80 \mathrm{~m}$ and are thus well resolved. Both the horizontal and vertical length scales are larger than those in the Korea Strait. The larger length scales are due to a weaker stratification in the Taiwan Strait. The Taiwan 
Strait measurements also do not resolve the near surface layer and thus shallow surface currents can be a source of error. Transports are computed by vertically integrating the interpolated velocity section. The time average transport over the three months is $0.14 \mathrm{~Sv}$ into the East China Sea and the standard deviation is $1.3 \mathrm{~Sv}$. The expected error in the transport based on the length scales is, at any time, about $0.33 \mathrm{~Sv}$.

Highest velocities in the Cheju Strait are expected to be near Cheju (Chang et al., 2000). Chang et al. (2000) have estimated transports through the Cheju Strait to range from about 0.4 to $0.7 \mathrm{~Sv}$. Transports in the Cheju Strait computed from the single mooring, located near Cheju, are scaled so that the time-average transport for the entire observation period (March-December, $1999)$ is $0.5 \mathrm{~Sv}$. Transports for the OctoberDecember time period are then $0.59 \mathrm{~Sv}$ and corresponding, average velocities through the Cheju Strait are about $60 \%$ of the velocities observed at the mooring.

Average transports for October-December, 1999 are $3.17 \mathrm{~Sv}$ for the Korea Strait, 0.59 Sv for the Cheju Strait, and 0.14 Sv for the Taiwan Strait. Transports as a function of time computed for the Taiwan, Cheju, and Korea Straits, are shown in
Fig. 3. Maximum volume transport in the Korea Strait between May 1999 and March 2000 occurs in October (Teague et al., 2002). In general, the observed volume transport through the Korea Strait is at a maximum during summer - fall and at a minimum during winter-spring (Kawabe, 1982; Toba et al., 1982; Isobe, 1994). The volume transport through the Taiwan Strait on monthly scales is not known but is believed to be episodic and greatly influenced by the winds. Isobe (1999) found that transport through the Taiwan Strait is at a minimum during the fall period which is a period for maximum transport through the Korea Strait. He used a diagnostic model with long-term hydrographic and wind data and determined that the origin of the TSC is through the Taiwan Strait throughout the year except during fall. A separation branch of the Kuroshio southwest of Kyushu was clearly identified in fall in his model. Thus, Isobe (1999) suggests that the origin of the TSC changes seasonally. The same scenario is also observed here for fall. Average transport from the ADCP measurements for the 1999 fall period through the Korea Strait $(3.17 \mathrm{~Sv})$ is much larger than the net transport through the Taiwan Strait (0.14 Sv).

Transport through the Taiwan Strait can be divided into time periods during which transport

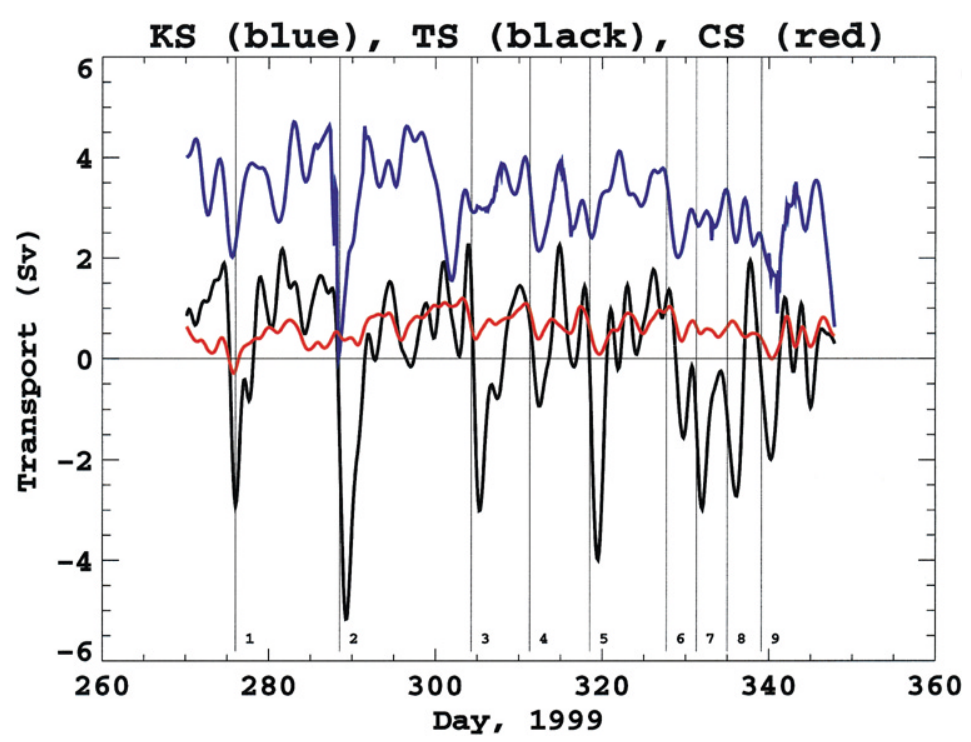

Fig. 3. Transports as a function of time (positive for flow to the north and east) are shown for the Korea Strait (blue line), Cheju Strait (red line), and Taiwan Strait (black line). Major wind events are marked by the light vertical lines numbered 1-9. 


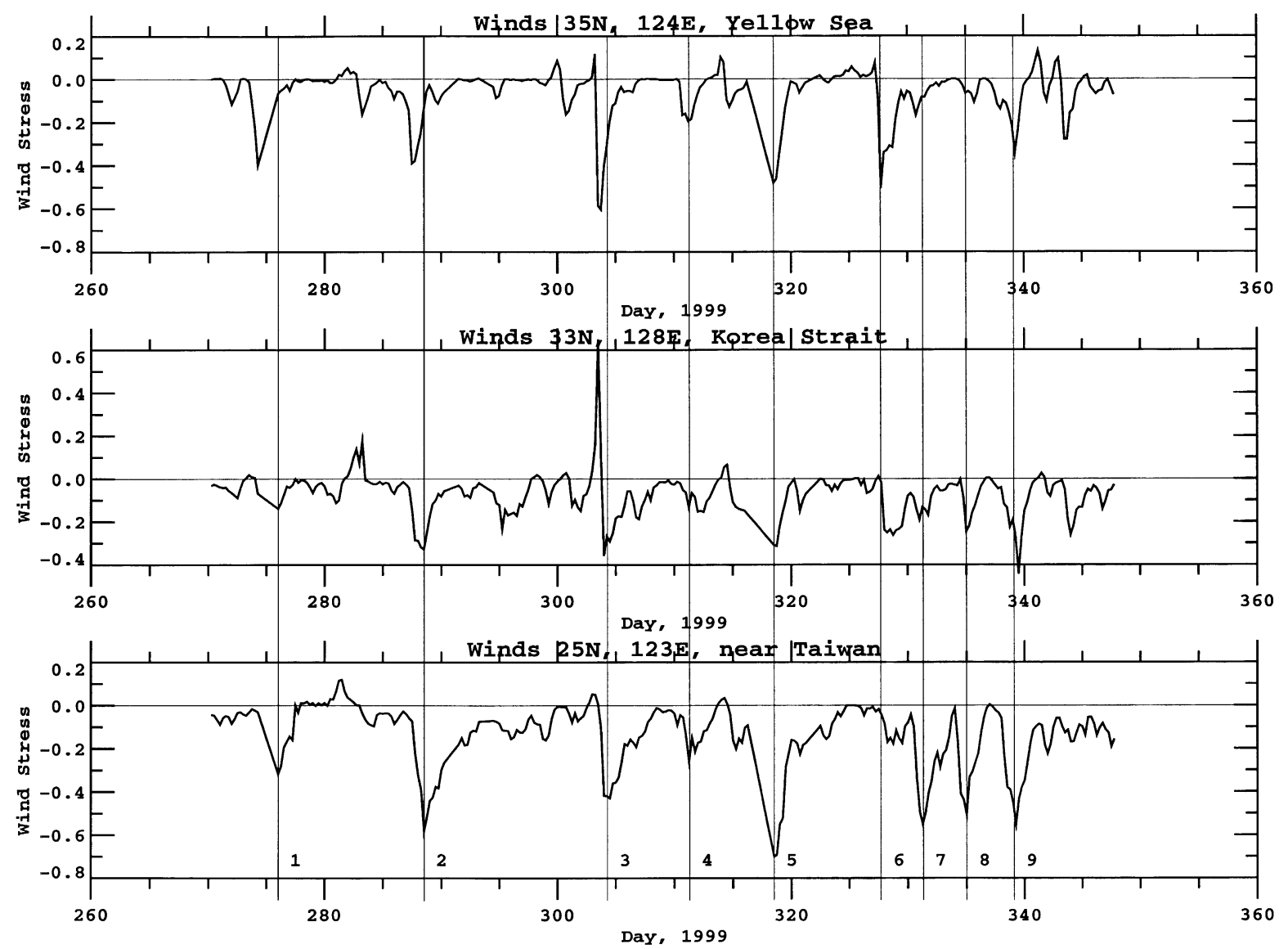

Fig. 4. North-south wind stress component at the three locations indicated in Fig. 2. Major wind events are marked by the light vertical lines numbered 1-9.

flows into the East China Sea and time periods during which transport flows into the South China Sea. The mean over time periods with flow into the East China Sea is $0.62 \mathrm{~Sv}$, and the mean over periods with flow into the South China Sea is $-0.49 \mathrm{~Sv}$. The flow into the South China Sea through the Taiwan Strait is most probably intensification of the southward flowing Chinese Coastal Current (CCC). Because of the large disparity between the flow through the Taiwan Strait and the Korea Strait, flow through the Taiwan Strait cannot be the primary source of the TSC for fall, 1999.

Transport fluctuations in each strait are dominated by periods ranging from 3 to 10 days. Variability range is much greater in the Korea and
Taiwan Straits than in the Cheju Strait. Some of the fluctuations appear to have the same forcing mechanism and, since the straits are all relatively shallow, are likely strongly affected by variations in the wind fields in which north-south wind stresses are dominant. Northward wind stresses provided by the Navy Operational Global Atmospheric Prediction System (NOGAPS) (Hogan and Brody, 1993; Rosmond, 1992; Hogan and Rosmond, 1991) at locations in the Yellow Sea, Korea Strait, and near Taiwan (Fig. 2), are shown in Fig. 4. Major southward wind events are marked by the light vertical lines numbered $1-9$ in Fig. 4 and are also shown in Fig. 3. Most striking are the northerly wind events (negative wind stress) and the resulting southward outflow through the 
Taiwan Strait (wind events 1-5 and 7-9). Peak outflow lags the northerly wind events by about 1 day. The large positive wind stress (southerly wind) near day 304 in the Korea Strait is associated with a rapidly developing cold air outbreak over China and the corresponding cyclonic low pressure system.

Several large transport fluctuations in the Korea Strait correspond with fluctuations in the Taiwan Strait (wind events 1 and 2). Other fluctuations seem to correspond in all three straits (wind events 1, 4, 5, 6, and 9). Correlations of the transports between straits are: 0.45 between the Korea and Taiwan Straits, 0.38 between the Taiwan and Cheju Straits, and 0.17 between the Korea and Cheju Straits. The transport within each strait is positively correlated to the observed wind field (Korea Strait: 0.40, Taiwan Strait: 0.54, Cheju Strait: 0.14). The correlation in transports between the Korea and Taiwan Straits is likely due to the large-scale nature of the wind field (0.66 correlation in the wind fields between the Korea and Taiwan Straits).

\section{Inferred transports}

Volume transports through the East China Sea are presented in Fig. 5. Only the transports through the Taiwan, Cheju, and Korea Straits are directly observed. Climatological values are used for the Kuroshio inflow (Hsueh et al., 1992; Ichikawa and Chaen, 2000; Johns et al., 2001) and river inflow (Gao et al., 1992) for the observation time period, and these numbers $(23.0$ and $0.03 \mathrm{~Sv}$, respectively) are in angle brackets. All other transports are inferred to balance the mass flux, and the inferred numbers are presented in parentheses.

The simultaneous measurements in the straits connecting the Yellow and East China Sea to the South China Sea and the JES present an opportunity to estimate mass flux onto the continental shelf, that is, across the boundary of the Yellow and East China Seas, that was not measured directly. The flow across the shelf break is due to Kuroshio intrusions, and these occur primarily in two areas. The first area is just northeast of

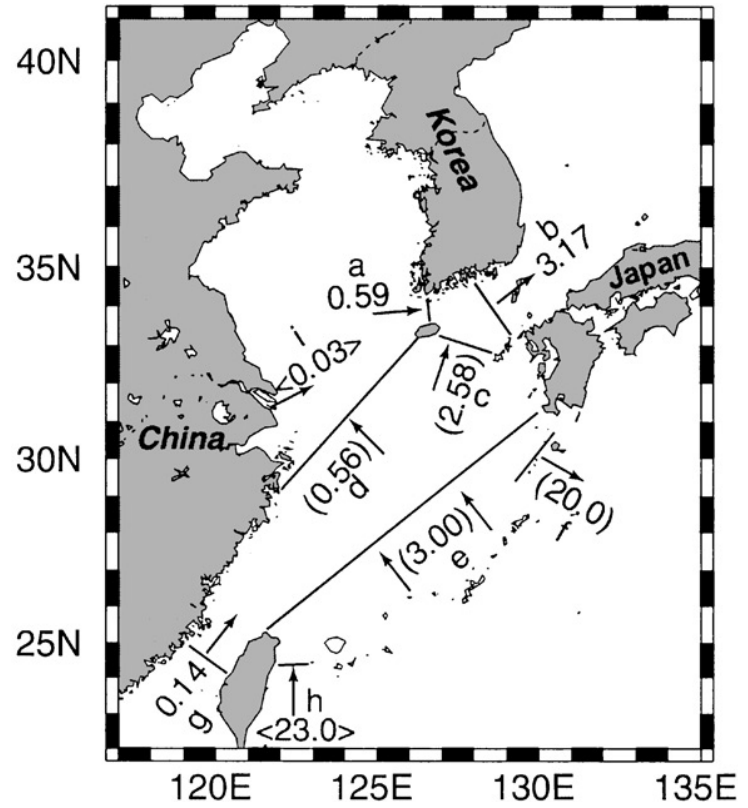

Fig. 5. Measured volume transports (a,b, and g), inferred (in parentheses) volume transports (c, d, e, and f), and climatological (in brackets) volume transports (h) and river outflows (i) are shown for October-December, 1999. Units are Sverdrups $\left(10^{6} \mathrm{~m}^{3} \mathrm{~s}^{-1}\right)$.

Taiwan where Kuroshio water spreads over the bottom of the shelf into the Yangtze (Changjiang) Relict River Valley (Jacobs et al., 2000). In addition, Kuroshio meanders extend far onto the shelf northeast of Taiwan and periodically shed eddies onto the shelf (Qiu, et al., 1990; Tang et al., 1999). The second area of Kuroshio intrusion onto the shelf, the TSC branch, occurs west of Kyushu and provides a much larger portion of the transport. Total transport across the shelf break onto the shelf is inferred using our observed transports. Specific locations of Kuroshio intrusions along the shelf break are not determinable. During the observation time period, estimated transport onto the shelf is $3.0 \mathrm{~Sv}$ and estimated transport through the Tokara Strait is $20 \mathrm{~Sv}$ ( $e=b-g-i$ and $f=h-e$ in Fig. 5, respectively).

In addition to the cross-shelf transport, the transport of $2.58 \mathrm{~Sv}$ south of Cheju into the Korea Strait given by $c=b-a$ and the transport of 
$0.56 \mathrm{~Sv}$ into the Yellow Sea given by $d=e+g-c$ (Fig. 5) are estimated. This is an important issue in determining how much water in the Tsushima Current flows on the north side of Cheju (as suggested by Lie, et al., 2000) and how much flows on the south side (as suggested by Nitani, 1972). Historically, the TSC has been interpreted as a branch of the Kuroshio (Suda and Hidaka, 1932), but more recent studies suggest complicated flow patterns in the region. Using hydrographic data, Lim (1971) suggested that TSC water is formed on the continental shelf region of the East China Sea by lateral mixing between the Kuroshio surface waters and the East China Sea waters. Nitani (1972) also suggested, based on hydrographic data, that the TSC separates from the Kuroshio southwest of Kyushu. On the other hand, Beardsley et al. (1985), also after analyzing hydrographic data, suggested that the TSC is a northeast continuation of the TWC that flows along the continental shelf region of the East China Sea. However, differences in physical properties between the water in the Taiwan Strait and Korea Strait (Lie and Cho, 1994) suggest that the waters in the two straits have different origins.

Changes of sea level, precipitation, and evaporation are not considered. An imbalance in transports through a particular subregion would cause a time rate of change in sea level. However, even a relatively large time rate of change of sea level ( $1 \mathrm{~m}$ over the observation period) would result in transport imbalances that are below the precision at which the numbers are presented. Similarly evaporation and precipitation over the observation time period would not make a significant impact on transport estimates.

From the transports through the East China Sea, we see that the TWC contributes only a small portion of the flow into the East China Sea $(0.14 \mathrm{~Sv})$. The bulk of the flow comes from the Kuroshio $(3.0 \mathrm{~Sv})$. The flow going from the East China Sea to the Yellow Sea $(0.56 \mathrm{~Sv})$ joins with the river inflow $(0.03 \mathrm{~Sv})$ and exits through the Cheju Strait $(0.59 \mathrm{~Sv})$. The fraction of the total flow (3.14 Sv) exiting the East China Sea by flowing into the Yellow Sea and then north of Cheju is $18 \%$ compared to $82 \%$ that exits the East China Sea by flowing south of Cheju.

\section{MODAS}

Temperatures and salinities are obtained from the Modular Ocean Data Assimilation System (MODAS) static climatology of temperature and salinity profiles (Fox et al., 2002). MODAS is one of the present US Navy standard tools for production of three-dimensional grids of temperature and salinity and is used for many of its operational systems. MODAS, recently developed at the Naval Research Laboratory, includes both a static climatology and a dynamic climatology. While the static climatology represents the historical averages, the dynamic climatology assimilates near-real-time observations of sea surface height and sea surface temperature. Only the static MODAS climatology will be used in the analyses here. Although similar to the Levitus climatology (Levitus, 1982; Conkright et al., 1999), the static MODAS climatology provides increased horizontal resolution particularly in coastal areas. The MODAS climatology used in the Asian seas region is a subset of the global MODAS temperature and salinity climatology which is stored bimonthly in time on a variable resolution mesh in space. MODAS spatial resolution ranges from $1 / 8$ to $1 /$ 4 degree in this region. In the upper $1500 \mathrm{~m}$ of water, MODAS is computed from historical temperature and salinity profiles from the Master Oceanographic Observation Data Set (MOODS; Teague et al., 1990) which have undergone rigorous editing. Additional temperature and salinity profiles from US Navy databases that were not available for the construction of the Levitus climatology are used in the construction of MODAS. MODAS relaxes to the Levitus climatology in the deep layers. The temperature observations are gridded by optimum interpolation to form a bimonthly temperature climatology at each grid node and depth. At each grid node, an expanding envelope in space and time is formed until an acceptable number of historical profiles are found. To prevent incompatible observations from being merged between geographically close but physically distinct regions, the various basins and straits of the world are provinced. For example, profiles in the Taiwan Strait can be combined with profiles in the East China Sea but 
not with profiles east of Taiwan in the Pacific Ocean. The climatology is computed for 26 levels in the upper $1500 \mathrm{~m}$. At each position, depth, and time of year, the relationship between salinity and temperature is determined by locally weighted linear regression from the subset of observations having both temperature and salinity. Distributions of historical temperature and salinity observations provide good coverage for bimonthly MODAS in the study area.

\section{Temperature and salinity transports}

The main influx of salt to the JES enters through the Korea Strait. The TSC, which transports warm saline water into the JES basin through the Korea Strait has a profound impact on the formation of fronts and eddies in the JES. The historical interpretation by Suda and Hidaka (1932) and by Uda (1934) that the TSC splits into three distinct branches after entering the JES is still widely accepted. However, others (Moriyasu, 1972) have interpreted the TSC as a single meandering current that episodically sheds eddies. Trajectories of satellite- tracked drifters analyzed by Beardsley et al. (1992) demonstrate that the TSC in the JES is quite complex in both space and time.

River discharge has the potential for a large effect on the salinity. The largest rivers in Asia, the Yangtze and Yellow (Huanghe) Rivers empty into the Yellow and Bohai Seas. In addition, there are smaller rivers along the west coast of Korea that add to the fresh water discharge into the Yellow Sea. The annual mean of the total river discharge is about $0.03 \mathrm{~Sv}$ (Gao et al., 1992). Maximum river outflow occurs during June and July. The Yangtze River's outflow generally peaks in July at about $0.05 \mathrm{~Sv}$ (Beardsley et al., 1985). The influx of Yangtze River diluted water has been observed as far east as Cheju (Park, 1986; Beardsley et al., 1985). The direct effects of rainfall are negligible since the yearly average value of evaporation is approximately equal to the annual mean precipitation in this region (Chen et al., 1994).

MODAS spatial resolution ranges from about $14 \mathrm{~km}$ (1/8 degree) within about $50 \mathrm{~km}$ of the coasts to $28 \mathrm{~km}(1 / 4$ degree) elsewhere in this region. The average monthly temperature and salinity (T\&S) values calculated from the MODAS static climatology are shown for the Cheju Strait, Korea Strait, the Taiwan Strait, and Kuroshio inflow in Fig. 6. Average monthly T\&S and their standard deviations for October-December, 1999 are shown in Fig. 7. Average T\&S for the Korea Strait and Taiwan Strait are the average values of the depth-averaged T\&S at the mooring locations spanning the Korea Strait (six locations) and the Taiwan Strait (four locations), respectively (Fig. 2). Average T\&S for the Cheju Strait are the average values of the depth-averaged T\&S at the mooring location in the Cheju Strait (Fig. 2) and at locations about 20 and $40 \mathrm{~km}$ north of this mooring. The average T\&S for the Kuroshio (Fig. 7, section h) are the average values of the
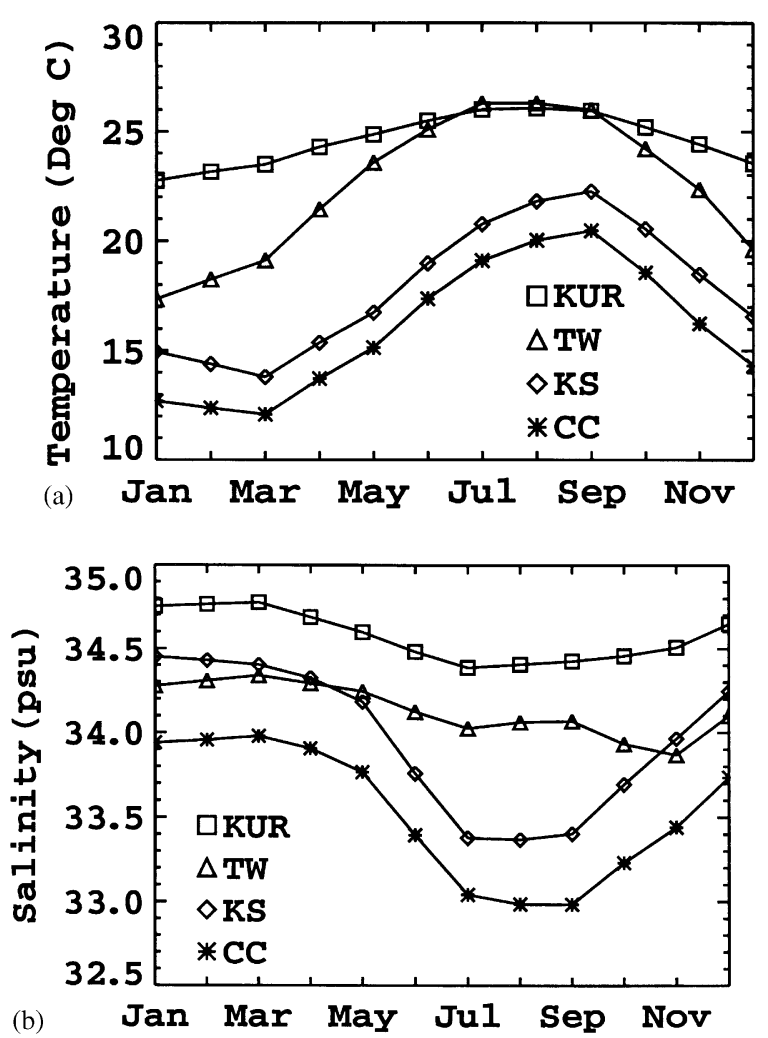

Fig. 6. (a) Average monthly temperatures for the Cheju Strait (CC), Korea Strait (KS), Taiwan Strait (TW), and the Kuroshio (KUR) are shown, (b) average monthly salinities are shown. Temperature and salinity are computed from the MODAS static climatology (Fox et al., 2002). 




Fig. 7. Average temperature $\left({ }^{\circ} \mathrm{C}\right)$ and standard deviation (top number) and average salinity (ppt) and standard deviation (bottom number) for the climatological October-December time period. Values are obtained from the MODAS climatology (Fox et al., 2002). Averages are formed from depthaveraged quantities at the locations indicated by the crosses. Kuroshio average T\&S values from MODAS at the entrance to the East China Sea are used for $e, f$, and $h$.

depth-averaged $\mathrm{T} \& \mathrm{~S}$ at five locations along an east-west line between Taiwan and Yonagunijima. The depth-averaged T\&S for the Kuroshio are calculated using just the upper $150 \mathrm{~m}$ of the profiles, which is about the depth of the East China Sea shelf. The Kuroshio T\&S values are also assumed along the East China Sea shelf break and for the Tokara Strait (Fig. 7, sections e and f, respectively).

The overall monthly variation in T\&S (Fig. 6) is strikingly similar between the Korea Strait and Cheju Strait. Lower salinities occurring between July and October in the Korea and Cheju Straits are due to river outflow. Salinity is about 0.3 psu higher in the Korea Strait than in the Cheju Strait. A similar pattern in salinity but with less range in variability and with much higher salinities is found for the Kuroshio waters. There exists a strong similarity in the monthly averaged salinities between the Kuroshio and Taiwan Strait waters for January-September. The monthly averaged temperatures for the Kuroshio and the Taiwan Strait waters are nearly the same for the summer months of July-September but diverge during the rest of the year. Since salinity is lower in the Taiwan Strait than in the Kuroshio by about $0.4 \mathrm{psu}$, source waters for the Taiwan Strait are greatly influenced by fresher sources that do not originate from the Kuroshio. These fresher sources are most likely from the South China Sea.

The average monthly salinity (S) can be used to calculate the salt transport $\left(S_{t}\right)$ into the JES:

$S_{t}=\rho V S$,

where $\rho$ is the average density of sea water (taken to be $1.025 \mathrm{~g} / \mathrm{cm}^{3}$ ) and $V$ is the volume transport. Similarly, the average monthly temperature (T) can be used to calculate the temperature transport $\left(T_{t}\right)$ :

$T_{t}=\rho C_{p} V T$,

where $C_{p}$ is the specific heat of sea water. The quantity $\rho C_{p}$ is approximated within the accuracy of the calculation as a constant value of $4.1 \times$ $10^{6} \mathrm{Jm}^{-3 \circ} \mathrm{C}^{-1}$ (Hall and Bryden, 1982). Using climatological T\&S for October-December, 1999 (shown with standard deviation in Fig. 7) along with the volume transports (Fig. 5), temperature and salt transports are calculated for each section (Figs. 8 and 9, respectively). Largest percentages of salt and temperature transports into the JES are attributed to the Kuroshio, estimated to contribute approximately $106.09 \times 10^{6} \mathrm{~kg} / \mathrm{s}$ of salt and $0.30 \times 10^{15} \mathrm{~W}$ of heat.

Errors in the volume transport and average temperature (average salinity) contribute to the errors in the temperature (salinity) transport. The error in volume transport of $3.17 \mathrm{~Sv}$ through the Korea Strait is approximately $0.5 \mathrm{~Sv}$ and errors in average temperature of $18.5^{\circ}$ and salinity of $34.0 \mathrm{psu}$ are approximated by their standard deviations of $1.2^{\circ}$ and $0.2 \mathrm{psu}$, respectively. Through application of a propagation of errors technique for products, described by Bevington (1969), and assuming that errors in volume transport are uncorrelated with temperature and salinity errors, errors in temperature and salinity 


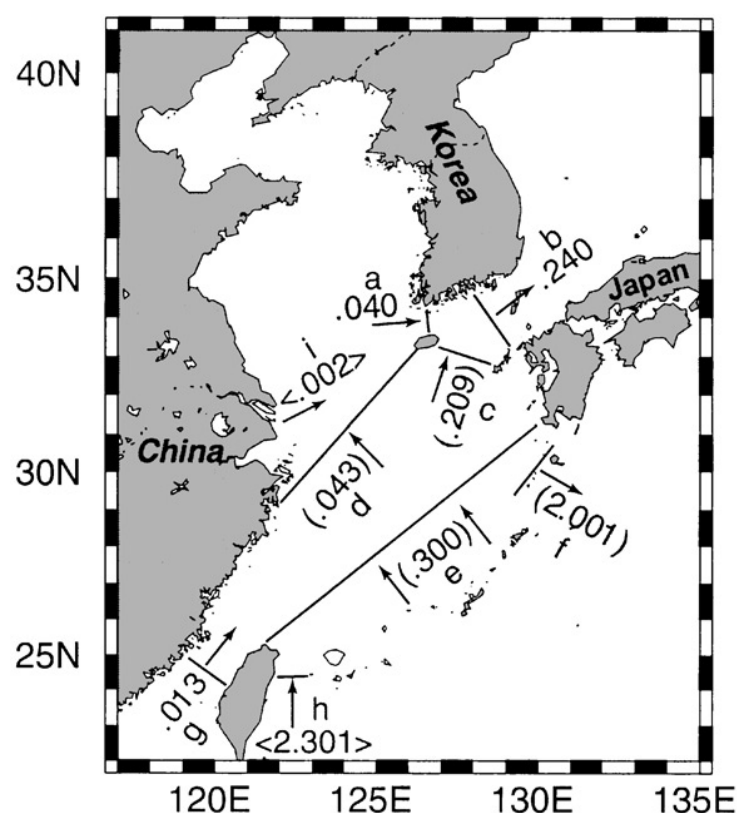

Fig. 8. Temperature transports $\left(\times 10^{15} \mathrm{~W}\right)$ are estimated from the values given in Figs. 5 and 7. The river temperature transport (i) assumes an average temperature of $18^{\circ} \mathrm{C}$ for the river inflow.

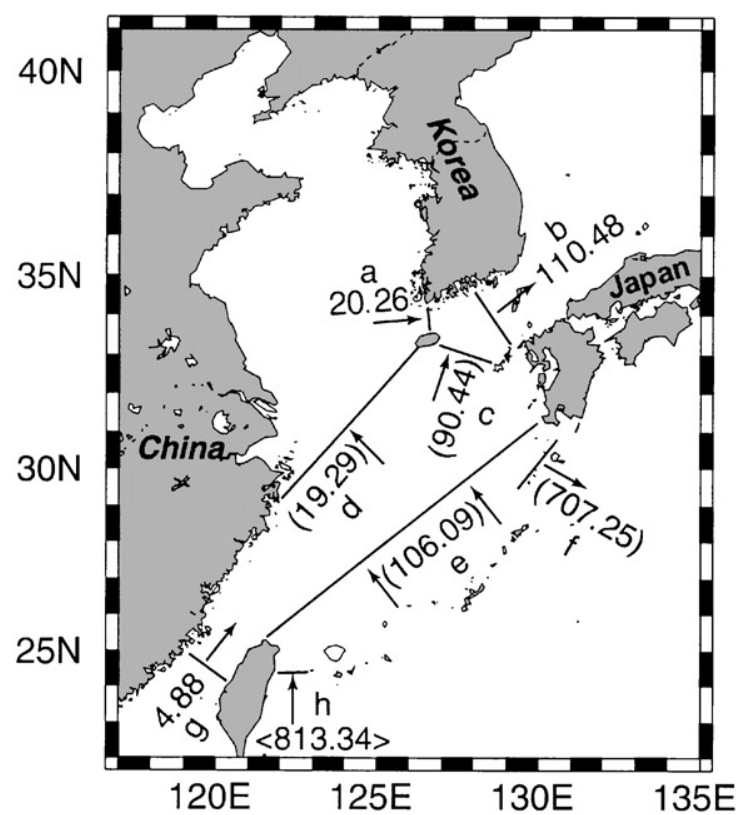

Fig. 9. Salinity transports $\left(\times 10^{6} \mathrm{~kg} \mathrm{~s}^{-1}\right)$ are estimated from the values given in Figs. 5 and 7. transports are $0.041 \times 10^{15} \mathrm{~W}$ and $17.44 \times$ $10^{6} \mathrm{~kg} / \mathrm{s}$ for the Korea Strait. Using a similar relative error in volume transport for the Taiwan Strait and corresponding standard deviations in temperature and salinity, errors in the temperature and salinity transports are $0.002 \times 10^{15} \mathrm{~W}$ and $0.77 \times 10^{6} \mathrm{~kg} / \mathrm{s}$, respectively. Errors in the volume transports contribute more to the flux errors than the errors in the climatological temperature and salinity estimations. The relative errors in the temperature transports are $17 \%$ for the Korea Strait and $15 \%$ for the Taiwan Strait. The relative error in the salinity transport is about $16 \%$ for both the Korea and Taiwan Straits. Relative temperature and salinity transport error estimates for the other sections shown in Figs. 8 and 9 are assumed similar.

Water volume transports for inflows and outflows (Fig. 5) balance by definition. However, temperature transports (Fig. 8), calculated using the balanced water transports and climatological $\mathrm{T}$ (Fig. 7) are not expected to balance since some heat may be lost to the atmosphere. The East China Sea region roughly bounded by $c, d, e$, and $g$ (Fig. 5) contains an area of about $3 \times 10^{11} \mathrm{~m}^{2}$. The net estimated heat loss in the East China Sea is $6.1 \times 10^{13} \mathrm{~W}(e+g-c-d)$ and yields a heat loss of about $200 \mathrm{~W} / \mathrm{m}^{2}$ which is about $20 \%$ of the net heat flux into the East China Sea. There is an estimated heat loss of $0.9 \times 10^{13} \mathrm{~W}(c+a-b)$ in the Korea Strait. Assuming an average temperature of $18^{\circ} \mathrm{C}$ for the river inflow, heat loss in the Yellow Sea is $0.5 \times 10^{13} \mathrm{~W}$ which is about half the heat loss in the Korea Strait. Therefore most of the Kuroshio heat loss occurs in the East China Sea. On the other hand, salt inflows should balance the outflows (Fig. 9) if water volume transports and T\&S estimates are accurate and assuming negligible evaporation and precipitation. Results shown in Fig. 9 show deficits of $0.49 \times 10^{6} \mathrm{~kg} / \mathrm{s}(e+g-$ $b$ ) of salt outflow in the Korea Strait and a deficit of $1.24 \times 10^{6} \mathrm{~kg} / \mathrm{s}$ in salt outflow for the East China Sea region bounded by c, d, e, and g. These errors are much less than $1 \%$ for the Korea Strait and about $1 \%$ for the East China Sea. A larger error in salt balance is found for the Yellow Sea where there is a deficit of $0.97 \times 10^{6} \mathrm{~kg} / \mathrm{s}(\mathrm{a}-\mathrm{d})$ or about $5 \%$ of the inflow. 


\section{Circulation}

In general, Taiwan Strait water is believed to flow northward throughout the year (Chuang, 1986; Chern and Wang, 1989), except for some surface water that is hypothesized to flow southward in winter (Chen et al., 1995). Beardsley et al. (1985) and Lie and Cho (1994) theorized that the TWC remains separated from the Kuroshio. However, the path of the Kuroshio northeast of Taiwan shows large seasonal variations and often extends well onto the shelf (Qiu and Imasato, 1990; Lin et al., 1992; Hsueh et al., 1992; Tang and Yang, 1993; Tang et al., 1999, 2000). Several theories try to explain the cause of the Kuroshio running onto the East China Sea shelf, or "branching" phenomenon. Modeling studies by Qiu and Imasato (1990) and by Hsueh et al. (1992) emphasized topographic effects and were capable of reproducing a significant amount of Kuroshio water flowing onto the shallow shelf without any external wind forcing. On the other hand, a modeling study by Chao (1990) found that the presence of the Kuroshio water on the East China Sea shelf in winter can be largely attributed to shelfward surface Ekman drift associated with the northerly wind. The existence of this Kuroshio branch current is verified by long-term GEK observations and by satellite observations (Qiu and Imasato, 1990). Tang et al. (1999) mapped the branch current using shipboard ADCP data.

Although given the data presented here we are not able to conclude the exact position at which the Kuroshio intrudes onto the shelf, historical observations do provide good evidence for this intrusion. The work here attempts to add quantitative transport determinations to the previous work. According to the frontal probability map of Hickox et al. (2000) and the frontal SST analysis of Zheng and Klemas (1982), the separation of the TSC from the KUR appears to occur at about $31.0^{\circ} \mathrm{N}$, about $0.5^{\circ}$ further north than determined by Nitani (1972). The bending around Cheju of the branch split off the TSC is also evident in SST analyses and hydrography (Chang et al., 2000; Lie et al., 2000). The southward coastal currents along the China and Korea coasts are both clear in the SST analyses. Evidence here strongly contradicts the proposed scenario given in Fig. 1b (Beardsley et al., 1985; Fang et al., 1991) in which a TWC coexists alongside of the KUR and flows through the Korea Strait. The balance of transports through the straits for the October-December, 1999 time period requires $3.00 \mathrm{~Sv}$ of Kuroshio water to flow onto the shelf.

A new circulation pattern is proposed for the Yellow and East China Seas in Fig. 10. The Kuroshio provides the bulk of the inflow into the East China Sea and the JES. The TWC either flows northward, or mixes with the Kuroshio (Jacobs et al., 2000) and flows eastward to the Korea Strait. The TSC branches off the Kuroshio and mostly flows directly through the Korea Strait and into the JES. In addition, a small branch forms off the TSC just south of Cheju and flows clockwise around Cheju, through the Cheju Strait into the Korea Strait, and into the JES. This current, called the Cheju Warm Current in the

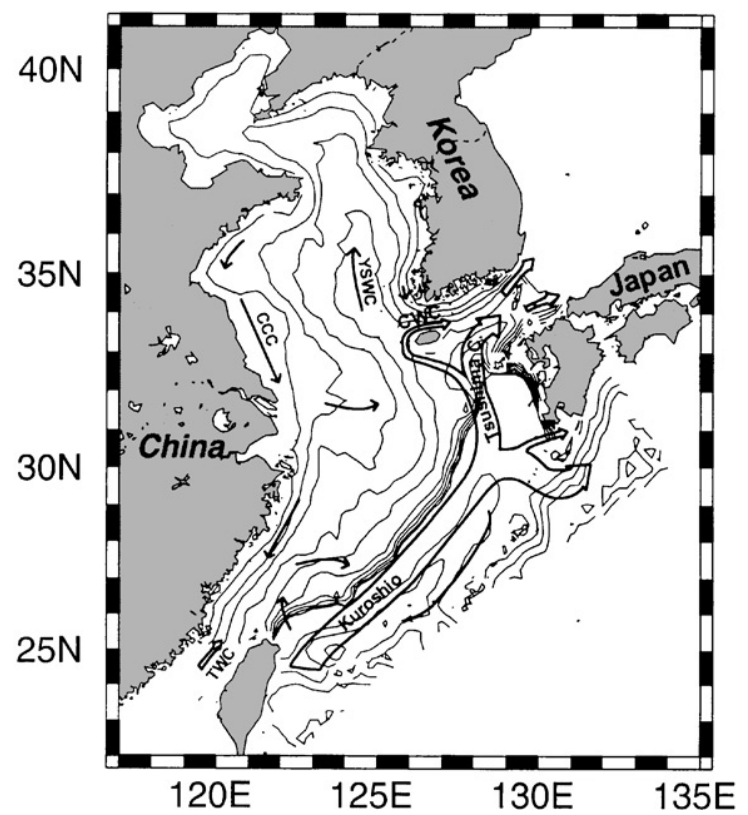

Fig. 10. A new circulation pattern is proposed for the Yellow and East China Seas. The Kuroshio Current provides the main inflow into the Japan/East Sea via the Tsushima Current and Cheju Current. Tsushima Current transport is larger in the western channel than in the eastern channel (west and east of Tsushima, respectively). The Yellow Sea Warm Current does not form off the Tsushima Current. The Taiwan Warm Current can commingle with the Kuroshio Current. 
Cheju Strait, is also modified by Yellow and East China Seas waters. The TSC volume transport is generally larger in the channel west of Tsushima Island. The major source of inflow into the JES is the Kuroshio for fall, 1999.

A similar picture is suggested by Isobe (1999). He finds that about $66 \%$ of the volume transport of the TSC comes directly from the Kuroshio in fall, crossing the shelf edge of the East China Sea as a separation branch southwest of Kyushu. However, he also suggests that a Taiwan-Tsushima Warm Current system exists for the remainder of the year.

\section{Conclusions}

Our observation period is October-December, 1999. Transports through the Korea Strait averaged approximately $3.17 \mathrm{~Sv}, 0.24 \times 10^{15} \mathrm{~W}$, and $110.48 \times 10^{6} \mathrm{~kg} / \mathrm{s}$. The bulk of flow through the Korea Strait must come from the Kuroshio flowing onto the shelf since the flow through the Taiwan Strait $(0.14 \mathrm{~Sv})$ is small. Some heat loss occurs in the Korea Strait but most of the Kuroshio heat loss occurs in the East China Sea at a rate of about $200 \mathrm{~W} / \mathrm{m}^{2}$, and little heat is lost in the Yellow Sea. The total volume transport through the Korea Strait is formed from Taiwan Warm Current and Kuroshio waters which may have been modified by Yellow Sea, East China Sea, and South China Sea waters, and by river outflows. Thus, about $95 \%$ of the transport into the JES is of Kuroshio origin for fall, 1999.

\section{Acknowledgements}

This work was supported by the Office of Naval Research as part of the Basic Research Projects "Linkages of Asian Marginal Seas" and "Japan East Sea DRI" under Program Element 0601153N (NRL-SSC contribution JA/7330/01/0082). K.-I. Chang and M.-S. Suk were supported by grants from the KORDI's in-house project "Marine Ecosystem Response to Climate Variability in the East Sea" under Project Number BSPE 00783-00-
1306-1. T.Y. Tang was supported under NCS 892119-M2002-016.

\section{References}

Beardsley, R.C., Limeburner, R., Yu, H., Cannon, G.A., 1985. Discharge of the Changjiang (Yangtze River) into the East China Sea. Continental Shelf Research 4, 57-76.

Beardsley, R.C., Limeburner, R., Kim, K., Candela, J., 1992. Lagrangian flow observations in the East China, Yellow and Japan Seas. La Mer 30, 297-314.

Bevington, P.R., 1969. Data Reduction and Error Analysis for the Physical Sciences. McGraw-Hill, New York, 336pp.

Chang, K.-I., Suk, M.-S., Pang, I.-C., Teague, W.J., 2000. Observations of the Cheju Current. Journal of the Korean Society of Oceanography 35, 129-152.

Chao, S.Y., 1990. Circulation of the East China Sea I: the Kuroshio influence. Journal of Oceanography Society of Japan 46, 273-295.

Chen, C., Beardsley, R.C., Limeburner, R., Kim, K., 1994. Comparison of winter and summer hydrographic observations in the Yellow and East China Sea and adjacent Kuroshio during 1986. Continental Shelf Research 14, 909-929.

Chen, C.T.A., Ruo, R., Pai, S.C., Liu, C.T., Wong, G.T.F., 1995. Exchange of water masses between the East China Sea and the Kuroshio off northeastern Taiwan. Continental Shelf Research 15, 19-39.

Chern, C.S., Wang, J., 1989. On the water masses at northern offshore area of Taiwan. Acta Oceanography of Taiwan 22, $14-32$.

Chern, C.-S., Wang, J., 1992. The influence of Taiwan Strait waters on the circulation of the Southern East China Sea. La mer 30, 223-228.

Cho, Y.-K., Kim, K., 1994. Two modes of the salinityminimum layer water in the Ulleung Basin. La Mer 32, $271-278$

Chuang, W.-S., 1986. A note on the driving mechanisms of current in the Taiwan Strait. Journal of Oceanography Society of Japan 42, 355-361.

Conkright, M.E., Levitus, S., O’Brien, T., Boyer, T.P., Stephens, C., Johnson, D., Baranova, O., Antonov, J., Gelfeld, R., Rochester, J., Forgy, C., 1999. World Ocean Database 1998, Version 2.0, National Oceanographic Data Center Internal Report 14. US Government Printing Office, Washington, DC.

Fang, G., Zhao, B., Zhu, Y., 1991. Water volume transport through the Taiwan Strait and the continental shelf of the East China Sea measured with current meters. In: Takano, K. (Ed.), Oceanography of Asian Marginal Seas. Elsevier, New York, pp. 345-358.

Fox, D.N., Teague, W.J., Barron, C.N., Carnes, M.R., Lee, C.M., 2002. The modular ocean data assimilation system (MODAS). Journal of Atmospheric and Oceanic Technology $19,240-252$. 
Gao, Y., Aromoto, R., Duce, R.A., Lee, D.S., Zhou, M., 1992. Input of atmospheric trace elements and mineral matter to the Yellow Sea during the spring of a low-dust year. Journal of Geophysical Research 97, 3767-3777.

Hall, M.M., Bryden, H.L., 1982. Direct estimates and mechanisms of ocean heat transport. Deep-Sea Research 29, 339-359.

Hickox, R., Belkin, I., Cornillon, P., Shan, Z., 2000. Climatology and seasonal variability of ocean fronts in the East China, Yellow and Bohai Seas from Satellite SST Data. Geophysical Research Letters 27 (18), 2945-2948.

Hogan, T.F., Rosmond, T.E., 1991. The description of the navy operational global atmospheric prediction system. Monthly Weather Review 119 (8), 1786-1815.

Hogan, T.F., Brody, L.R., 1993. Sensitivity studies of the Navy global forecast model parameterizations and evaluation of improvements to NOGAPS. Monthly Weather Review 121 (8), 2373-2395.

Hsueh, Y., 1988. Recent current observations in the eastern Yellow Sea. Journal of Geophysical Research 93, 68756884.

Hsueh, Y., Wang, J., Chern, C.-S., 1992. The intrusion of the Kuroshio across the continental shelf northeast of Taiwan. Journal of Geophysical Research 97, 14 323-14 330.

Ichikawa, H., Beardsley, R.C., 1993. Temporal and spatial variability of volume transport of the Kuroshio in the East China Sea. Deep-Sea Research 40, 583-605.

Ichikawa, H., Chaen, M., 2000. Seasonal variation of heat and freshwater transports by the Kuroshio in the East China Sea. Journal of Marine Systems 24, 119-129.

Isobe, A., 1994. Seasonal variability of the barotropic and baroclinic motion in the Tsushima-Korea Strait. Journal of Oceanography 50, 223-238.

Isobe, A., 1999. On the origin of the Tsushima Warm Current and its seasonality. Continental Shelf Research 19, 117-133.

Jacobs, G.A., Hur, H.B., Riedlinger, S.K., 2000. Yellow and East China Seas response to winds and currents. Journal of Geophysical Research 105, 21 947-21968.

Jacobs, G.A., Perkins, H.T., Teague, W.J., Hogan, P.J., 2001. Summer transport through the Korea-Tsushima Strait. Journal of Geophysical Research 106, 6917-6929.

Johns, W.E., Lee, T.N., Zhang, D., Zantopp, R., Liu, C.-T., Yang, Y., 2001. The Kuroshio East of Taiwan. Moored Transport Observations from the WOCE PCM-1 Array. Journal of Physical Oceanography 31, 1031-1053.

Kawabe, M., 1982. Branching of the Tsushima Current in the Japan Sea, Part 1. Data analysis. Journal of Oceanography Society of Japan 38, 95-107.

Kim, K., Rho, H.K., Lee, S.H., 1991a. Water masses and circulation around Cheju-do in summer. Journal of Oceanology Korea 26, 262-277.

Kim, K., Kim, K.-R., Rhee, T.S., Rho, H.K., Limeburner, R., Beardsley, R.C., 1991b. Identification of water masses in the Yellow Sea and the East China Sea by cluster analysis. In: Takano, K. (Ed.), Oceanography of Asian Marginal Seas, Elsevier Oceanography Series, Vol. 54. Elsevier, Amsterdam, pp. 253-267.
Kim, I.-O., Rho, H.-K., 1994. A study on China coastal water appearing in the neighbouring seas of Cheju Island (in Korean with English abstract). Bulletin of the Korean Fisheries Society 27, 515-528.

Levitus, S., 1982. Climatological atlas of the world ocean, 1982. NOAA Professional Papers, 13, 173pp.

Lie, H.-J., Cho, C.-H., 1994. On the origin of the Tsushima Warm Current. Journal of Geophysical Research 99, 25081-25091.

Lie, H.-J., Cho, C.-H., Lee, J.-H., Lee, S., Tang, Y., 2000. Seasonal variation of the Cheju Warm Current in the northern East China Sea. Journal of Oceanography 56, 197-211.

Lim, B., 1971. On the origin of the Tsushima Current water. Journal of Oceanology Society of Korea 6, 85-91.

Lin, C.-Y., Shyu, C.-Z., Shih, W.-H., 1992. The Kuroshio fronts and cold eddies off northeastern Taiwan observed by NOAA-AVHRR imageries. Terrestrial Atmospheric and Oceanic Sciences 3, 225-242.

Moriyasu, S., 1972. The Tsushima Current. In: Stommel, H., Yoshida, K. (Eds.), Kuroshio: Its Physical Aspects. University of Tokyo Press, Tokyo, pp. 353-369.

Nitani, H., 1972. Beginning of the Kuroshio. In: Stommel, H., Yoshida, K. (Eds.), Kuroshio. University of Tokyo Press, Tokyo, Japan, pp. 353-369.

Park, Y.H., 1986. Water characteristics and movements of the Yellow Sea Warm Current in summer. Progress in Oceanography 17, 243-254.

Perkins, H., Teague, W.J., Jacobs, G.A., Chang, K.-I., Suk, M.S., 2000. Currents in Korea-Tsushima Strait During Summer 1999. Geophysical Research Letters 27 (19), 3033-3036.

Qiu, B., Imasato, N., 1990. A numerical study on the formation of the Kuroshio countercurrent and the Kuroshio branch current in the East China Sea. Continental Shelf Research $10,165-184$.

Qiu, B., Toda, T., Imasato, N., 1990. On Kuroshio Front Fluctuations in the East China Sea using satellite and in situ observational data. Journal of Geophysical Research 95, 18 191-18 204.

Rosmond, T.E., 1992. The design and testing of the Navy Operational Global Atmospheric Prediction System. Weather and Forecasting 7 (2), 262-272.

Schultz, J.R., 1994. A numerical model of the Kuroshio in the East China Sea. Cooperative Thesis No. 157, Florida State University, Tallahassee, FL and National Center for Atmospheric Research, Boulder, CO, 144pp.

Suda, K., Hidaka, K., 1932. The results of the oceanographical observations aboard R.M.S. Syunpu Maru in the southern part of the Sea of Japan in the summer of 1929, part 1. Journal of Oceanography Imports and Marine Observations 3, 291-375 (in Japanese).

Tang, T.Y., Yang, Y.J., 1993. Low frequency current variability on the shelf break northeast of Taiwan. Journal of Oceanography 49, 193-210.

Tang, T.Y., Hsueh, Y., Yang, Y.J, Ma, J.C., 1999. Continental slope flow northeast of Taiwan. Journal of Physical Oceanography 29, 1353-1362. 
Tang, T.Y., Tai, J.H., Yang, Y.J., 2000. The flow pattern north of Taiwan and the migration of the Kuroshio. Continental Shelf Research 20, 349-371.

Teague, W.J., Jacobs, G.A., 2000. Current observations on the development of the Yellow Sea Warm Current. Journal of Geophysical Research 105 (C2), 3401-3411.

Teague, W.J., Carron, M.J., Hogan, P.J., 1990. A comparison between the Generalized Digital Environmental Model and Levitus climatologies. Journal of Geophysical Research 95 (C5), 7167-7183.

Teague, W.J., Jacobs, G.A., Perkins, H.T., Book, J.W., Chang, K.-I., Suk, M.-S., 2002. Low frequency current observations in the Korea Strait. Journal of Physical Oceanography $1621-1641$.

Toba, Y., Tomizawa, K., Kurasawa, Y., Hanawa, K., 1982. Seasonal and year-to-year variability of the TsushimaTsugaru Warm Current system with its possible cause. La Mer 20, 41-51.
Uda, M., 1934. The results of simultaneous oceanographical investigations in the Japan Sea and its adjacent waters in May and June, 1932. Japan Imports and Fisheries Exports Stations 5, 57-190 (in Japanese).

Wang, J., Chern, C.-S., 1996. Some aspects on the circulation in the northern South China Sea. La mer 34, 246-257.

Wyrtki, K., 1961. Physical oceanography of the southeast Asian water. NAGA Report Vol. 2, Scientific results of marine investigations of the South China Sea and the Gulf of Thailand, Scripps Institution of Oceanography, La Jolla, CA.

Zhang, D., Lee, T.N., Johns, W.E., Liu, C.-T., Zantop, R., 2001. The Kuroshio East of Taiwan: modes of variability and relationship to interior ocean Mesoscale Eddies. Journal of Physical Oceanography 31, 1054-1074.

Zheng, Q., Klemas, V., 1982. Determination of winter temperature patterns, fronts, and surface currents in the Yellow Sea and East China Sea from satellite imagery. Remote Sensing of Environment 12, 201-218. 